\title{
The dentin chemical degradation and saliva roles on Noncarious Cervical Lesions - literature review
}

Paola Gomes Souza ${ }^{a}$, Alexandre Coelho Machado ${ }^{b}$, Analice Giovani Pereira $^{\mathrm{a}}$, Renata Roland Teixeira ${ }^{\mathrm{c}}$, Foued Salmen Espíndola ${ }^{\mathrm{c}}$, Paulo Vinícius Soares ${ }^{\mathrm{d}}$

\begin{abstract}
This review elucidates the dental structure chemical degradation and saliva roles in the origin and progression of NCCLs. Dentin chemical degradation is a predominant factor that contributes to the origin and progression of noncarious cervical lesions, which includes the biocorrosive factors: chemical, biochemical, electrochemical and piezoelectric dentin effects. The biocorrosive process involves endogenous and exogenous agents. As regard to saliva roles, the flow rate, buffering capacity, $\mathrm{pH}$ and its protein composition are valid parameters to identify biocorrosive factors. Thus, the association of acids agents, altered salivary parameters and specifics proteases are important conditions to promote dental wear. It can be concluded that endogenous and exogenous acids agents, salivary parameters and specific oral biomarkers are important to support the diagnostic and management of dental wear and noncarious cervical lesions.
\end{abstract}

Keywords: diet; gastroesophageal reflux; saliva; tooth erosion; tooth wear.

\section{A degradação química da dentina e os papéis da saliva nas lesões cervicais não cariosas - revisão da literatura}

\section{RESUMO}

Esta revisão elucida a degradação química da estrutura dental e os papéis da saliva na origem e progressão de lesões cervicais não cariosas. A degradação química da dentina é um fator predominante que contribui para a origem e progressão de lesões cervicais não cariosas que incluem fatores biocorrosivos: efeitos químicos, bioquímicos, eletroquímicos e proteolíticos da dentina. O processo biocorrosivo envolve agentes endógenos e exógenos. No que diz respeito aos papéis da saliva, a taxa de fluxo, a capacidade de tamponamento, o pH e sua composição proteica são parâmetros válidos para identificar fatores biocorrosivos. Assim, a associação de agentes ácidos, parâmetros salivares alterados e proteases específicas são condições importantes para promover o desgaste dental. Pode-se concluir que os agentes ácidos endógenos e exógenos, parâmetros salivares e biomarcadores orais específicos são importantes para apoiar o diagnóstico e manejo do desgaste dentário e lesões cervicais não cariosas.

Palavras-chave: dieta; refluxo gastroesofágico; saliva; erosão dentária; desgaste dos dentes. a NCCL Research Group, Operative Dentistry and Dental Materials Department, School of Dentistry, Federal University of Uberlandia, Uberlandia, Minas Gerais, Brazil

${ }^{b}$ NCCL Research Group, Technical Health School, Federal University of Uberlandia, Uberlandia, Minas Gerais, Brazil

${ }^{c}$ Institute of Genetics and Biochemistry, Federal University of Uberlandia, Uberlandia, Minas Gerais, Brazil

${ }^{d}$ Coordinator of NCCL Research Group, Operative Dentistry and Dental Materials Department, School of Dentistry, Federal University of Uberlandia, Uberlandia, Minas Gerais, Brazil

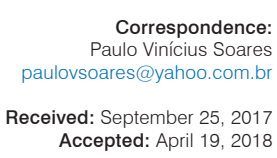

Accepted: April 19, 2018

Conflict of Interests: The authors state that there re no financial and personal conflicts of interest that could have inappropriately influenced their work.

Copyright: (๑) 2017 Souza et al licensee EDIPUCRS.

This work is licensed under a Creative Commons Attribution 4.0 International License. 


\section{INTRODUCTION}

Noncarious Cervical Lesions (NCCLs) are characterized by hard tissue loss in the cement-enamel junction (CEJ) [1-4]. NCCLs are commonly found in dental practice, with prevalence rates up to $85 \%$ [5]. The origin and progression of theses lesions are related to three etiological factors: stress (tensile/compressive stress concentration), biocorrosion (acid-induced dentin chemical degradation) and friction (attrition and abrasion) [2,6]. Although there is no consensus regarding the diagnostic and management of NCCLs, the knowledge of multifactorial etiology is important to prevent more aggressive dental structure damage (Figure 1) [7,8].

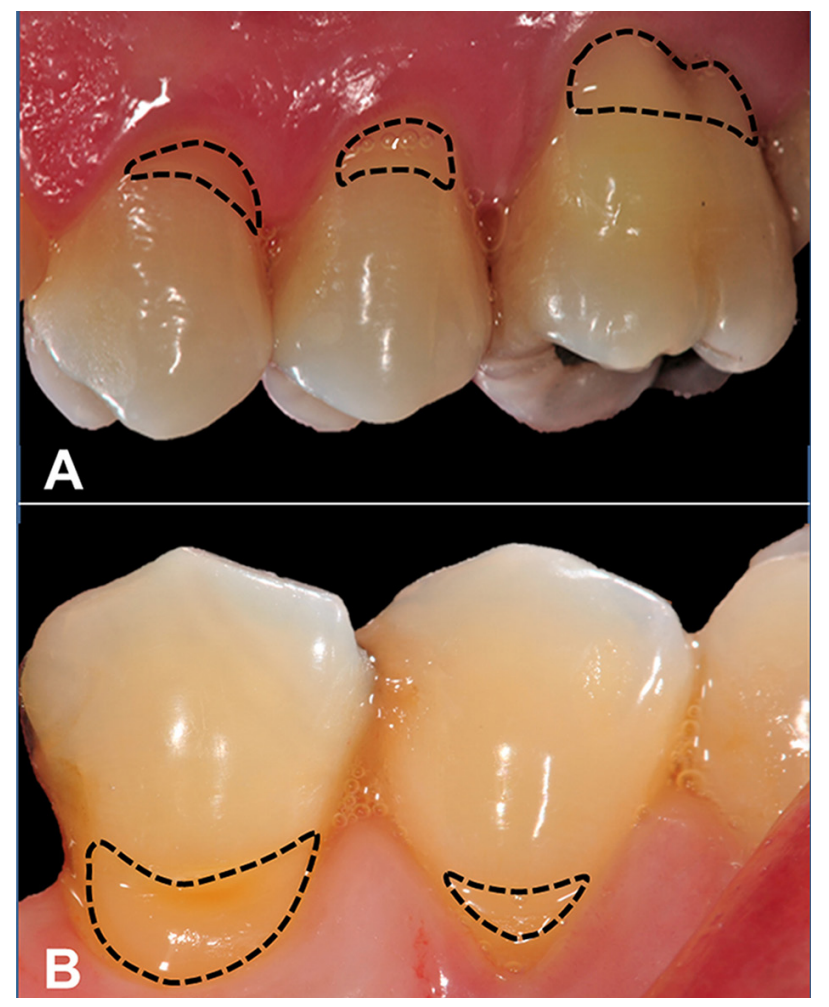

The biocorrosion process refers to the chemical, biochemical and electrochemical degradation of the tooth structure caused by the activity of acid agents, proteolytic and piezoelectric effects [3]. This process occurs at the microstructural dental tissues level and it is potentialized by friction and stress [9-11]. The pathogenesis of the chemical degradation is related to endogenous (proteases, GERD) and exogenous (dietary habits, physical exercise, oral hygiene and lifestyle) factors, besides biological factors $[7,11,12]$.

The term "dental erosion" has been widely used in literature to refer to the tooth wear as consequence of acid degradation, however, the process of tooth surface erosion is characterized by the movement of liquids and corrosive fluids in constant contact with the dental structure, being therefore a physical wear mechanism $[2,13,14]$. Differently, the biocorrosion is a complex process involving chemical reactions between acids derived from different origins and the components of dental structures and, therefore, a biochemical process of degradation $[3,15,16]$.

The saliva conditions influence the capability of biocorrosive wear and is related to salivary parameters, composition and salivary pellicle thickness $[6,17]$. Furthermore, salivares tests can be used to determine highrisk patients and biocorrosive process to prevent more aggressive dental wear (Figure 2) [18]. Thus, the purpose of this literature review was to elucidate the dental structure chemical degradation and saliva roles in the origin and progression of NCCLs.

\section{Dentin chemical degradation mechanisms and endogenous/exogenous acids}

The dental chemical degradation process is promoted for endogenous and exogenous acids, proteolytic agents and piezoelectric effects [6]. Exposure by acids agents is frequent in some populations, caused by endogenous acids (presented on biofilm, gingival crevicular fluid and gastric juice) or exogenous agents (diet behavior and occupational habits) $[2,18-21]$.

Figure 1. Saliva in contact with teeth with NCCLs. A - Maxillary teeth; B - Mandibular teeth.

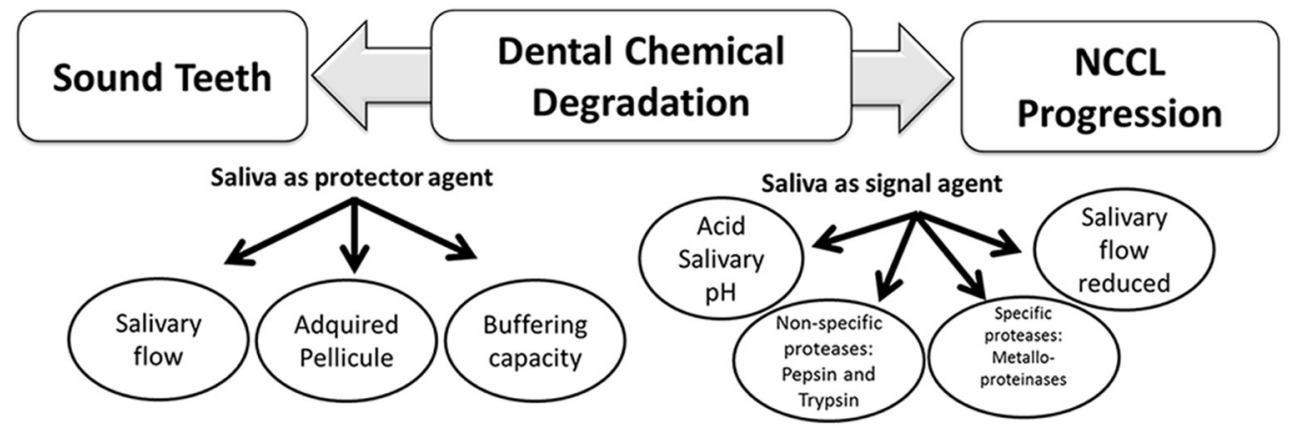

Figure 2. Structural criteria and parameters addressed salivary in dentinal degradation and Noncarious Cervical Lesions progression and Causal factors of the dentin chemical degradation process. 
Patients with gastroesophageal disorders, such as gastroesophageal reflux, bulimia, regurgitation, and periodic vomiting, were found to be at high risk for dental endogenous biocorrosive processes [12,17,20-22]. The severity of dental wear and chemical degradation of the structures due to gastrointestinal disorders is directly related to the duration and frequency of the acid reflux, area of acid in contact, $\mathrm{pH}$ and saliva flow [23]. Some patients with bulimia may not present wear caused by acidic substances due to their salivary parameters, such as buffering capacity and flow rate $[7,12]$.

Exogenous acids from food and diet behaviors, such as citrus fruits and juices, carbonated beverages, sports drinks, teas, vinegars, vegetables and other foods, have high biocorrosive potential [24]. These types of foods are composed of several acids, such as citric, tartaric, phosphoric and lactic acid, which contribute to the increased risk of dental chemical degradation, since they have $\mathrm{pH}$ below the critical level for the corrosion of the dental structure $(\mathrm{pH}$ of 5,5$)[25,26]$. In this way, the exogenous agents accelerate the dentin chemical degradation, which is related to NCCLs origin and progression [5]. The first clinical signs of biocorrosive tooth wear manifests as changes in the optical properties of the enamel, followed by changes in the original tissue morphology [11]. The pattern of chemical degradation can be modulated by protective factors as the tooth position [21]. It justified the higher prevalence of NCCLs in the buccal face due to greater contact to acidic substances and lower amount of serous saliva [17].

\section{Saliva roles as protective, signaling and diagnostic agent}

Saliva is composed by inorganic and organic components. The inorganic components are related to bicarbonate buffering capacity of the saliva, while calcium and phosphate contribute to tooth mineral integrity $[17,27]$. Organic composition is related to proteins and glycoproteins, which influence many aspects of oral health. Intact histatins were identified in vivo and are responsible for salivary pellicle formation [27]. Moreover, the organic components are attributed to anti-demineralization properties [27,28]. The mucins prevent desiccation because their viscoelastic properties provide adequate lubrication and contribute to protector effect of salivary pellicle against metalloproteinases and biocorrosion [28]. Before contacting the enamel, acids must diffuse through a film of mucins, glycoproteins and other enzymes to reach the tooth $[28,29]$.

Salivary flow is a measure of saliva secreted at rest or stimulated in a given time, expressed in $\mathrm{ml} /$ minute. It can be produced at rest or under mechanical, gustatory, olfactory and psychological stimulation [29]. Chemical degradation can be associated with low salivary, the decrease in salivary flow may be associated with aging, medications, irradiated patients and in cases of exercise excessive [30,31]. Low salivary flow, impaired output of total protein, amylase and electrolytes are influenced by acute alcohol consumption and increase chance to development of NCCLs [29]. The hypersalivation and high buffering capacity are associated to lower prevalence of NCCLs, even on individuals with acids habits or gastrointestinal disturbances [32,33]. This is considered a defensive mechanism and it acts producing serous saliva in higher volume and with greater concentration of glycoconjugate, protein and bicarbonate in comparison with asymptomatic controls [34].

Unstimulated flow rate and higher chloride concentration are independent factors that contribute to dental wear [35]. On the other hand, the presence of calcium and total protein is responsible to form the salivary pellicle and to difficult the acids effects on dental surface $[28,34]$. This pellicle acts as diffusion barrier of serous saliva in intimate contact and strongly adhered to the dental surface $[17,36]$. Furthermore, many proteins present salivary pellicle, which shows an important role against dental chemistry degradation $[17,28,34,36]$.

Another important salivary parameter is the buffering capacity. This parameter is responsible for the neutralization and dilution of acids that cause tooth wear. It occurs by maintaining constant oral $\mathrm{pH}$ and eliminating acidic substances through swallowing, contributing to the reduction of tooth structure loss. In a stage of ideal buffering capacity and neutral $\mathrm{pH}$, saliva is supersaturated in relation to the solubility products of hydroxyapatite, that is, the enamel will gain calcium and phosphate, since there are more of these ions in the salivary fluid than in the enamel $[23,36]$.

In a stage of compromising buffer capacity and presence of acidic substances saliva presents a low concentration of calcium and phosphate, which will cause, to the tooth, the loss of these ions to the saliva in an attempt to maintain the balance, generating the dental degradation. However, if this situation does not last for a long period, the $\mathrm{pH}$ returns to normal $(>5.5)$ and the normal buffering capacity and saliva supersaturation will be restored $[17,37]$.

The loss of tooth structure tends to be more aggressive conforming the salivary $\mathrm{pH}$ decrease [23]. This fact is reflected by the acceleration of mechanical stress wear after the immersion of samples in acidic solution [38]. Salivary $\mathrm{pH}$ is variable and its action is determined not only by the acidity, but also by the interaction between the components of the solution and the levels of saturated ionic components [39]. Acid solutions act on salivary calcium and phosphate, reducing the salivary saturation and influencing the concentration gradient in the oral environment. The $\mathrm{pH}$ measures the degree of acidity, neutrality or alkalinity of a solution $[39,40]$. A lower salivary $\mathrm{pH}$ activates specific proteases that degrade extracellular matrix proteins and different forms of collagen [36,38].

The acid diet ingestion results in salivary $\mathrm{pH}$ decrease and it stays lower for a longer period of time [40]. Moreover, the saliva parameters show a lower buffering capacity of $\mathrm{pH}$ at $5.5[38,40]$. On the other hand, organic material on the tooth structure reduces the demineralization rate by increasing the amount of collagen phosphoproteins, thereby slowing the progression of chemical degradation [30]. 
Through the analysis of the complex salivary composition, it may be possible to identify biochemical markers that indicate the presence of a particular disease, condition or change [41]. These biomarkers could be used to evaluate biological and physical states [41,42]. Proteins and peptides were identified as the ideal salivary biomarkers for diagnostics [42]. However, to use these components as diagnostics, their basal states in saliva must be known [43]. Some biomarkers of stress in saliva can be important as cofactor to the development of several oral diseases, once higher hydrocortisone concentrations significantly up regulated the expression of matrix metalloproteinase (MMP) -1, -2, -7, and -11 and tissue inhibitor of MMP (TIMP)-1 in human gingival fibroblasts, which might constitute a mechanism for periodontitis and dentin degradation [44]. However, new studies are necessaries to discovery specific biomarkers to cervical dentin degradation [45].

\section{Proteolytic agents and piezoelectric effect in dentin}

Proteases are cysteine, serine, threonine, aspartate and metalloproteinase groups, which regulate the activity of proteins and enzymes in cells and saliva flow [46]. Trypsin and pepsin are proteases that influence dentin chemical degradation, particularly in patients with gastric disorders $[46,47]$. The optimum $\mathrm{pH}$ for pepsin activation is between 1 and 3, commonly on situations with reflux of gastric juice [47]. However, trypsin activation occurs in neutral/basic $\mathrm{pH}$ (between 7 and 8) and this inactivation occurs on presence of acids $\mathrm{pH}$, for example during the vomiting [46]. The presence of calcium and other neutralizing factors can contribute to trypsin reactivation [48].

The release of non-collagen proteins on proteolytic agents alters dentin collagen and makes it more susceptible to collagen proteases $[46,47,49]$. Around $27-57 \%$ collagen was degraded by collagenase, after contact to acid substances $(\mathrm{pH}=4)$, and it facilitates dentin degradation and NCCLs progression [2,49]. Proteolytic enzymes promote dentin hydrolysis, demineralization and modulate the salivary pellicle [12]. Proteolytic activity alters the collagen non-helical molecule, containing inter and intramolecular crosslinks, and dentin collagen crosslinks are responsible for the high insolubility and homogeneity of collagen [50,51]. Trypsin also demineralizes dentin and removes other proteins that maintain the collagen structure, including non-collagenous proteins phosphoproteins, proteoglycans, glycoproteins and gamma-carboxyglutamate acid [52] aiding the biocorrosive process.

The proteolytic metalloproteases (MMPs) enzymes matrix change the biofilm and residual organic matrix of dentin [30]. This enzyme is present in desmineralized dentin in its active form, which degrades and disorganizes the dentin matrix [10]. The active MMPs include the biocorrosive MMP-1 and MMP-8, collagenases MMP-2 and MMP-9, and gelatinases, which are acid-resistant and activated by lowering the $\mathrm{pH}[12]$.
Therefore, nonspecific enzymes, such as pepsin, cathepsin and trypsin, can interact with other enzymes and contribute to the activation of specific enzymes MMPs [53]. These findings have led to the development and use of chemical agents to minimize the deleterious effects of acidic conditions, inhibit the action of MMPs and the piezoelectric effect [51].

The piezoelectric effect happens when the dentin generates an electrical surface charge upon application of load [54]. The magnitude of dental tissue piezoelectricity is of $0.027 \mathrm{pC} / \mathrm{N}[54,55]$. The differential piezoelectric behavior could be account by chemical differences in the collagens and microarchitecture feature in dentine [55]. This effect depends of matrix and organic components, therefore, enamel that does not present piezoelectricity effect $[54,55]$.

Thus, risk patients, for example bulimic patients, without signs of dentin chemical degradation probably have increased salivary protective properties and also increased flow rate that promotes a thicker salivary pellicle to improve tooth structure protection from proteolytic enzymes [22]. Therefore, the knowledge about events that promote alterations in the oral environment is extremely important in the treatment of damage caused and the care needed during the procedures in clinical practice [23].

\section{CONCLUSIONS}

Dental structure chemical degradation contributes to origin and progression of noncarious cervical lesions. The presence of endogenous and exogenous acids agents, flow salivary rate, buffering capacity, $\mathrm{pH}$, protein composition and proteolytic agents are valid parameters to identify biocorrosive process. Further studies are needed to relate the laboratory and clinical findings on the development of diagnostic methods, saliva tests and treatments for noncarious cervical lesions.

\section{REFERENCES}

1. Pecie R, Krejci I, Garcia-Godoy F, Bortolotto T. Noncarious cervical lesionsa clinical concept based on the literature review. Part 1: prevention. Am J Dent 2011; 24:49-56.

2. Grippo JO, Simring M, Coleman TA. Abfraction, abrasion, biocorrosion and the enigma of noncarious cervical lesions: a 20-year perspective. J Esthet Restor Dent 2012; 24:10-23. https://doi.org/10.1111/j.17088240.2011.00487.x

3. Michael JA, Townsend GC, Greenwood LF, Kaidonis JA. Abfraction: separating fact from fiction. Aust Dent J 2009; 54:2-8. https://doi. org/10.1111/j.1834-7819.2008.01080.x

4. Nguyen C, Ranjitkar S, Kaidonis JA, Townsend GC. A qualitative assessment of non-carious cervical lesions in extracted human teeth. Aust Dent J. 2008; 53:46-51. https://doi.org/10.1111/j.1834-7819.2007.00009.x

5. Levitch LC, Bader JD, Shugars DA, Heymann HO. Non-carious cervical lesions. J Dent 1994; 22:195-207. https://doi.org/10.1016/03005712(94)90107-4

6. Grippo JO. Abfractions: a new classification of hard tissue lesions of teeth J Esthet Dent 1991; 3:14-9. https://doi.org/10.1111/j.1708-8240.1991. tb00799.x

7. Lussi A, Jaeggi T. Erosion-diagnosis and risk factors. Clin Oral Investig 2008; 12:5-13. https://doi.org/10.1007/s00784-007-0179-z

8. Khan F, Young WG, Shahabi S, Daley TJ. Dental cervical lesions associated with occlusal erosion and attrition. Aust Dent J 1999; 44:176-86. https:// doi.org/10.1111/j.1834-7819.1999.tb00219.x

9. Eisenburger $M$, Addy $M$. Influence of liquid temperature and flow rate on enamel erosion and surface softening. J Oral Rehabil 2003; 30: 1076-80. https://doi.org/10.1046/j.1365-2842.2003.01193.x 
10. Litonjua LA, Andreana S, Patra AK, Cohen RE. An assessment of stress analyses in the theory of abfraction. Biomed Mater Eng 2004; 14:311-21

11. Soares PV, Souza LV, Veríssimo C, Zeola LF, Pereira AG, Santos-Filho, PC, Fernandes-Neto AJ. Effect of root morphology on biomechanical behaviour of premolars associated with abfraction lesions and different loading types. J Oral Rehabil 2014; 41:108-14. https://doi.org/10.1111/joor.12113

12. Schlueter N, Ganss C, Pötschke S, Klimek J, Hannig C. Enzyme activities in the oral fluids of patients suffering from bulimia: a controlled clinical trial. Caries Res 2012; 46:130-9. https://doi.org/10.1159/000337105

13. Marsicano JA, de Moura-Grec PG, Bonato RC, Sales-Peres Mde C, Sales-Peres A, Sales-Peres SH. Gastroesophageal reflux, dental erosion, and halitosis in epidemiological surveys: a systematic review. Eur J Gastroenterol Hepatol 2013; 25:135-41. https://doi.org/10.1097/ MEG.0b013e32835ae8f7

14. Needleman I, Ashley P, Petrie A, Fortune F, Turner W, Jones J, Niggli J, Engebretsen L, Budgett R, Donos N, Clough T, Porter S. Oral health and impact on performance of athletes participating in the London 2012 Olympic Games: a cross-sectional study. Br J Sports Med 2013; 47: 1054-8. https://doi.org/10.1136/bjsports-2013-092891

15. Grippo JO, Simring M, Schreiner S. Attrition, abrasion, corrosion and abfraction revisited: a new perspective on tooth surface lesions. J Am Dent Assoc 2004; 135:1109-18. https://doi.org/10.14219/jada. archive.2004.0369

16. Featherstone JD, Lussi A. Understanding the chemistry of dental erosion Monogr Oral Sci 2006; 20:66-76. https://doi.org/10.1159/000093351

17. Young WG, Khan F. Sites of dental erosion are saliva-dependent. J Oral Rehabil 2002; 29:35-43. https://doi.org/10.1046/j.1365-2842.2002.00808.x

18. Kanzow P, Wegehaupt FJ, Attin T, Wiegand A. Etiology and pathogenesis of dental erosion. Quintessence Int 2016; 47:275-8.

19. Shen P, Walker GD, Yuan Y, Reynolds C, Stacey MA, Reynolds EC. Food acid content and erosive potential of sugar-free confections. Aust Dent $J$ 2017;20. https://doi.org/10.1111/adj.12498

20. Stefański T, Postek-Stefańska L. Possible ways of reducing dental erosive potential of acidic beverages. Aust Dent J 2014; 59:280-8. https://doi. org/10.1111/adj.12201

21. Barron RP, Carmichael RP, Marcon MA, Sàndor GK. Dental erosion in gastroesophageal reflux disease. J Can Dent Assoc 2003; 69:84-9.

22. Ranjitkar S, Smales RJ, Kaidonis JA. Oral manifestations of gastroesophageal reflux disease. J Gastroenterol Hepatol 2002; 27: 21-7. https://doi.org/10.1111/j.1440-1746.2011.06945.x

23. Su JM, Tsamtsouris A, Laskou M. Gastroesophageal reflux in children with cerebral palsy and its relationship to erosion of primary and permanent teeth. Journal of the Massachusetts Dental Society 2003; 52:20-24.

24. Marshall TA. Dietary assessment and counseling for dental erosion. J Am Dent Assoc 2018; 149:148-152. https://doi.org/10.1016/j.adaj.2017.11.006

25. Tahmassebi JF, Duggal MS, Malik-Kotru G, Curzon ME. Soft drinks and dental health: a review of the current literature. J Dent 2006; 34:2-11. https://doi.org/10.1016/j.jdent.2004.11.006

26. Meurman JH, Ten Cate JM. Pathogenesis and modifying factors of dental erosion. Eur J Oral Sci 1996; 104:199-206. https://doi. org/10.1111/j.1600-0722.1996.tb00068.x

27. Saxegaard E, Rolla G. Fluoride acquisition on and in human enamel during topical application in vitro. Scand J Dent Res 1988; 96:523-35. https://doi. org/10.1111/j.1600-0722.1988.tb01592.x

28. Nieuw Amerongen $\mathrm{AV}$, Oderkerk $\mathrm{CH}$, Driessen $\mathrm{AA}$. Role of mucins from human whole saliva in the protection of tooth enamel against demineralization in vitro. Caries Res 1987; 21:297-309. https://doi. org/10.1159/000261033

29. Enberg N, Alho H, Loimaranta V. Lenander-Lumikari M. Saliva flow rate, amylase activity, and protein and electrolyte concentrations in saliva after acute alcohol consumption. Oral Surg Oral Med Oral Pathol Oral Radiol Endod 2001; 92:292-8. https://doi.org/10.1067/moe.2001.116814

30. Botta SB, Ana PA, Santos MO, Zezell DM, Matos AB. Effect of dental tissue conditioners and matrix metalloproteinase inhibitors on type I collagen microstructure analyzed by Fourier transform infrared spectroscopy. J Biomed Mater Res B Appl Biomater 2012; 100:1009-16. https://doi. org/10.1002/jbm.b.32666

31. Dreizen S, Brown LR, Daly TE, Drane JB. Prevention of xerostomia-related dental caries in irradiated cancer patients. J Dent Res 1977; 56:99-104. https://doi.org/10.1177/00220345770560022101

32. Valena V, Young WG. Dental erosion patterns from intrinsic acid regurgitation and vomiting. Aust Dent J 2002; 47:106-15.
33. Hall HD. Protective and maintenance functions of human saliva. Quintessence Int 1993; 24:813-6.

34. Yandrapu H, Marcinkiewicz M, Poplawski C, Han K, Zbroch T, Goldin G Sarosiek I, Namiot Z, Sarosiek J. Role of saliva in esophageal defense: implications in patients with nonerosive reflux disease. Am J Med Sci 2015; 349:385-91. https://doi.org/10.1097/MAJ.0000000000000443

35. Saksena R, Bartlett DW, Smith BG. The role of saliva in regurgitation erosion. Eur J Prosthodont Restor Dent 1999; 7:121-4

36. Buzalaf MA, Hannas AR, Kato MT. Saliva and dental erosion. J Appl Oral Sci 2012; 20:493-502. https://doi.org/10.1590/S1678-77572012000500001

37. Lussi A, Jaeggi T, Zero D. The role of diet in the aetiology of dental erosion. Caries Res 2004; 38:34-44. https://doi.org/10.1159/000074360

38. Mishra P, Palamara JE, Tyas MJ, Burrow MF. Effect of static loading of dentin beams at various $\mathrm{pH}$ levels. Calcif Tissue Int 2006; 79:416-21. https://doi.org/10.1007/s00223-005-0271-9

39. Dawes $\mathrm{C}$. What is the critical $\mathrm{pH}$ and why does a tooth dissolve in acid? J Can Dent Assoc 2003; 69:722-4.

40. Lussi A, Von Salis-Marincek M, Ganss C, Hellwig E, Cheaib Z, Jaeggi $\mathrm{T}$. Clinical study monitoring the $\mathrm{pH}$ on tooth surfaces in patients with and without erosion. Caries Res 2012; 46:507-12. https://doi. org/10.1159/000339783

41. Tabak LA. Point-of-care diagnostics enter the mouth. Ann N Y Acad Sci 2007; 1098:7-14. https://doi.org/10.1196/annals.1384.043

42. Pereira AL, Cortelli SC, Aquino DR, Franco GC, Cogo K, Rodrigues E, Costa FO, Holzhausen M, Cortelli JR. Reduction of salivary arginine catabolic activity through periodontal therapy. Quintessence Int 2012 43:777-87

43. Oppenheim FG, Salih E, Siqueira WL, Zhang W, Helmerhorst EJ. Salivary proteome and its genetic polymorphisms. Ann N Y Acad Sci 2007; 1098:22-50. https://doi.org/10.1196/annals.1384.030

44. Rai B, Kaur J, Anand SC, Jacobs R. Salivary stress markers, stress, and periodontitis: a pilot study. J Periodontol 2011; 82:287-92. https://doi. org/10.1902/jop.2010.100319

45. Güncü GN, Yilmaz D, Könönen E, Gürsoy UK. Salivary Antimicrobial Peptides in Early Detection of Periodontitis. Front Cell Infect Microbiol 2015; 24:5-99. https://doi.org/10.3389/fcimb.2015.00099

46. Bedran-Russo AK, Pereira PN, Duarte WR, Okuyama K, Yamauchi M. Removal of dentin matrix proteoglycans by trypsin digestion and its effect on dentin bonding. J Biomed Mater Res B Appl Biomater 2008; 85:261-6. https://doi.org/10.1002/jbm.b.30944

47. Schlueter N, Ganss C, Hardt M, Schegietz D, Klimek J. Effect of pepsin on erosive tissue loss and the efficacy of fluoridation measures in dentine in vitro. Acta Odontol Scand 2007; 65:298-305. https://doi org/10.1080/00016350701678733

48. Saksena R, Bartlett DW, Smith BG. The role of saliva in regurgitation erosion. Eur J Prosthodont Restor Dent 1999; 7:121-4

49. Dung SZ, Li Y, Dunipace AJ, Stookey GK. Degradation of insoluble bovine collagen and human dentine collagen pretreated in vitro with lactic acid, pH 4.0 and 5.5. Arch Oral Biol 1994; 39:901-5. https://doi. org/10.1016/0003-9969(94)90022-1

50. Mishra P. Palamara JE, Tyas MJ, Burrow MF. Effect of static loading of dentin beams at various $\mathrm{pH}$ levels. Calcif Tissue Int 2006; 79:416-21. https://doi.org/10.1007/s00223-005-0271-9

51. Kuboki Y, Tsuzaki M, Sasaki S, Liu CF, Mechanic GL. Location of the intermolecular cross-links in bovine dentin collagen, solubilization with trypsin and isolation of cross-link peptides containing dihydroxylysinonorleucine and pyridinoline. Biochem Biophys Res Commun 1981; 102:119-26. https://doi.org/10.1016/0006-291X(81)91497-2

52. Walter C, Kress E, Götz H, Taylor K, Willershausen I, Zampelis A. The anatomy of non-carious cervical lesions. Clin Oral Investig 2014; 18 : 139-46. https://doi.org/10.1007/s00784-013-0960-0

53. Schlueter N, Hardt M, Klimek J, Ganss C. Influence of the digestive enzymes trypsin and pepsin in vitro on the progression of erosion in dentine. Arch Oral Biol 2010; 55:294-9. https://doi.org/10.1016/i. archoralbio.2010.02.003

54. Marino AA, Gross BD. Piezoelectricity in cementum, dentine and bone. Arch Oral Biol 1989; 34:507-9. https://doi.org/10.1016/0003-9969(89)90087-3

55. Liboff AR, Shamos MH. Piezoelectric effect in dentin. J Dent Res 1971; 50:516. https://doi.org/10.1177/00220345710500027901 